\title{
Fraud Prevention of Government Procurement of Goods and Services in Local Government
}

\author{
Dewi Kusuma Wardani ${ }^{1}$, Anita Primastiwi ${ }^{2}$, and Hanisah ${ }^{3}$ \\ ${ }_{1,2}$ Program Studi Akuntansi, Fakultas Ekonomi \\ ${ }^{3}$ Universitas Sarjanawiyata Tamansiswa Yogyakarta Indonesia \\ Email address: \\ d3wikusuma@gmail.com; anita.primas@ustjogja.ac.id; hanisaannisa97@gmail.com
}

\begin{abstract}
Referring to the government's efforts to prevent fraud, this study aims to provide empirical evidence regarding the effect of the implementation of eprocurement, whistleblowing system, and the Government Internal Control System (SPIP) on the prevention of fraud in the procurement of goods and services. Sampling used purposive sampling technique, and hypothesis testing using the PLS method using the SmartPLS 3 program. Data collection was carried out in May 2019. The research sample was 68 procurement actors who had served at least 1 year in the Procurement Service Unit (ULP), Inspectorate, and Health Office in Yogyakarta City. The results of this study indicate that the application of e-procurement, whistleblowing system, and SPIP has a positive effect on fraud prevention in the process of procuring goods and services in Yogyakarta City.
\end{abstract}

Keywords: E-procurement, whistleblowing, internal control, and fraudulent.

\begin{abstract}
Abstrak: Mengacu pada upaya pemerintah di dalam melakukan pencegahan terjadinya kecurangan, penelitian ini bertujuan untuk memberikan bukti empiris mengenai pengaruh penerapan e-procurement, whistleblowing system, dan Sistem Pengendalian Internal Pemerintah (SPIP) terhadap pencegahan kecurangan dalam pengadaan barang dan jasa. Pengambilan sampel menggunakan teknik purposive sampling, dan pengujian hipotesis menggunakan metode PLS dengan menggunakan program SmartPLS 3. Pengambilan data dilaksanakan pada bulan Mei 2019. Sampel penelitian adalah 68 pelaku pengadaan yang telah menjabat minimal 1 tahun di Unit Layanan Pengadaan (ULP), Inspektorat, dan Dinas Kesehatan di Kota Yogyakarta. Hasil penelitian ini menunjukkan bahwa penerapan e-procurement, whistleblowing system, dan SPIP berpengaruh positif terhadap pencegahan kecurangan di dalam proses pengadaan barang dan jasa di Kota Yogyakarta.
\end{abstract}

Kata Kunci: E-procurement, Whistleblowing, SPIP, dan Pencegahan Kecurangan.

\section{INTRODUCTION}

The increasing development of facilities and infrastructure in Indonesia must surely be balanced with the goods and services procurement. But in its implementation, 
there are various irregularities in the technique of procurement of government goods and services. The Corruption Eradication Commission stated that $70 \%$ of corruption in Indonesia originating from the procurement is an area prone to corruption in Indonesia. The government has poured a large budget for capitation funds through the health insurance organizing agency (BPJS). In 2016, 9,767 puskesmas and other first-level health facilities (FKTP) throughout Indonesia received Rp. 13 trillion in capitation funds. In 2017 capitation funds released are estimated at Rp. 14 trillion. On average each FKTP will get a capitation fund of Rp. 400 million per year (ICW, 2018).

The results of monitoring the Indonesian Corruption Watch (ICW) against the potential for corruption of capitation funds in FKTP regionally owned, there were eight cases in the range of the year 2014-2018. The state losses incurred reached Rp. 5.8 billion, including this case involving several health services in Indonesia both the district and city health offices. In this case, the Yogyakarta City health service was also involved in capitation fund utilization. In addition to the above case, there is a case of suspected corruption of more than $\mathrm{Rp} 21$ billion, which involves an educational institution in Yogyakarta (JawaPos.com 2018). The allegation of corruption is related to the procurement of operational goods in 2015-2016. The case began to be investigated since December 2016 related to the findings of hundreds of funds suspected of proceeds of corruption in the Office of the Training Institute (Kantor Lembaga Diklat).Various government efforts to increase transparency and accountability in the process of procurement, so that corruption in the environment of this area can be prevented. Prevention of fraudulent procurement of goods and services through policies that have been carried out by the government is by implementing e-procurement, whistleblowing systems, and government internal control systems. Presidential Regulation Number 16 the Year 2018 states that all procurement packages are carried out through electronic procurement, also, the government makes policies to implement a whistleblowing system in every government agency where the use of the whistleblowing system is as a means for someone to report fraud actions as regulated in LKPP Policy Number 11 of 2014. The government's internal control system according to (COSO, 2013) is having elements that must be applied in the government environment, particularly the manipulate environment, hazard assessment, manage activities, information and communication, and monitoring.

The fundamental principle of the authorities' procurement of goods and services is to get the right items at the right price, e-procurement can be necessary tool to limit the chance of fraud in the procurement of authorities items and services. (Udoyono, 2012) emphasizes that e-procurement can be an instrument to reduce corruption, collusion, and nepotism due to the fact via e-procurement the public sale is open so that more rational bids will show up. (LKPP, 2011) explains that the stages that can be carried out with e-procurement are the planning stage, the committee formation stage, the pre-qualification stage, the auction document preparation stage, the announcement, the registration and collection of auction documents, an explanation, the document entry and opening stage, the bid evaluation stage, the announcement stage, and the rebuttal stage. (LKPP, 2011) shows that the role of e-procurement at this stage is to apply the concept of transparency, for example, the publication of a general plan for procurement of stuffs and services on the Inaproc website, through LPSE and the concept of data interoperability in e-procurement which serves to reduce false 
documents. The higher the application of e-procurement, the higher the level of fraud prevention. Research that supports the implementation of e-procurement has a nice impact on the prevention of fraudulent procurement of items and services, namely research conducted by (Fisol et al., 2014), (Dewi, 2018), (Artanti et al., 2016). In contrast, research conducted by (Jaffa, 2014), (Lisa, 2016) states that the implementation of e-procurement does no longer have a substantial impact on fraud prevention.

One of the functions and authorities of the inspectorate as part of the Government Internal Control Apparatus (Aparat Pengawasan Intern Pemerintah/APIP) is to detect and investigate fraud. The government internal control device has to be carried out by all events in the government and regional environment, the place the implementation of the government's internal control system within the government can achieve effective, efficient, transparent, accountable, and responsible management of state finances. The government's internal control system gives contribution in preventing fraud because all activities in the procurement of stuffs and services will be monitored and supervised by the authorities. Previous research that supports that the implementation of a government's internal control system gives good effect on the prevention of fraudulent procurement of goods and services, namely research conducted by (Sulaiman, 2016), (Puspananda, 2016), and (Utami, 2016). In contrast, previous research by (Sinaga and Ananda, 2018) on the government's internal control system did no longer have a extensive effect on fraud prevention.

The fraud in the procurement of government stuffs and services has to be prevented by making another effort, that is to implement a whistleblowing system. Based on the Presidential Regulation of the Republic of Indonesia Number 10 of 2016 concerning actions to prevent and eradicate corruption, the efforts made include strengthening the internal control and supervision system in the Institution by optimizing the whistleblowing system. This whistleblowing system illustrates the openness of information in government administration as well as transparency and accountability in financial management. The whistleblowing system is a forum for a whistleblower to report fraud or violations committed by internal parties of the (Wahyuni and Nova, 2018). (Susmanci, 2012) states that someone who informs the public or powerful officials about allegations of dishonesty, illegal activities, or mistakes that occur in government, public or private organizations is called a whistleblower (Ahmad, 2017). It is hoped that the handling of the whistleblowing system will increase awareness for the internal organization in maintaining its integrity, because if not then the whistleblower will report information about their fraud in carrying out their duties and result in the imposition of sanctions. Research that supports that the whistleblowing system has a great effect in preventing the fraud is research conducted by (Wahyuni and Nova, 2018), (Akbar, 2018), (Wardana et al., 2017). On the other hand, research by (Titaheluw, 2011) states that the whistleblowing system has no significant effect on fraud prevention.

Based on the description above, this research aims to discover out how high the level of the prevention of fraudulent procurement of goods and offerings by imposing authorities insurance policies particularly e-procurement, Whistleblowing systems, and internal control systems. Based on the phenomenon that shows that the fraud that occurs is the lack of effective policies from the government, according to (Tuanakotta, 
2016), the factors that encourage someone to commit fraud are the opportunity, pressure, and rationale.

\section{THEORITICAL REVIEW}

Theory of Bureaucratic Reform. Indonesia, based on the basic concept of reform is to make changes, improvements, structuring, and regulation comprehensively and systematically on many matters especially those related to the state, organizational, and governance system, is a developing country. (Hendrayaday, 2011). Another theorywas emphasized by (Widjaja, 2011) saying that reform was an effort meant that political, government, economic and socio-cultural practices that were considered by the community to be incompatible and not in harmony with the interests of the community were changed and arranged to be more appropriate and in harmony (social reformation). According to KEMENPAN No.15 of 2015 bureaucratic reform is a strategic step to develop the resources of the professional state apparatus, has usability and professional results to support the running of the government and national development. Based on an understanding of the concepts of reform and bureaucracy, bureaucratic reform is broadly an improvement, change, or refinement of a system and organization to realize good governance effectively and efficiently so that it is free from fraud.

The annual report from the KPK explains that corruption cases from 2011-2015 originated from the realization of the stuffs and services procurement. The electronic procurement system has been needed to be implemented in full since the 2012 fiscal year. This was confirmed by the issuance of Presidential Regulation No. 70 of 2012 concerning the government's goods and services procurement. (Purwanto, 2008) defines that e-procurement is an application to manage goods and services procurement data which includes internet-based procurement data that is designed to achieve an effective, efficient, and integrated procurement process. The cause of e-procurement is to amplify transparency and accountability, amplify market get right of entry to and business competition, expand the level of efficiency of the procurement process, assist the monitoring and audit procedure and meet the desires of the trendy facts access, (Willem, 2012). Implementation of e-procurement is predicted to grant big advantages to the procurement of the government's items and services. The benefits of eprocurement are divided into two categories, specifically efficient and tremendous (Wijaya, 2010).E-procurement efficiency includes low costs, accelerates time in information, and integrates procurement functions as key in the back-office system, while the effectiveness of e-procurement is to increase control of the value chain, good management of important data, and improve the quality of decision returns in the purchasing process of the organization (Ahmad, 2018).

The theory of bureaucratic reform can be implemented in internal control systems, for example in decision making, monitoring, planning that is efficient and effective in carrying out governance. (Wilopo, 2015) states that the high intensity of fraud, fraud, and embezzlement practices that occur in a public or private institution, with all its modes, from simple to very low and complicated, should make all events working in their fields conscious to build dedication to the implementation of the machine accurate management, besides the awareness and evidence will result in no 
longer reaching the performance of accurate goods and services procurement. As a reaction to demands from the community to restore the function of the government as the administration of the state and as a community service, the government bureaucracy must realize good governance.

Based on the description above, it can be concluded that the theory of bureaucratic reform refers to changes in systems or procedures in the procurement of government goods and services. In this study, bureaucratic reform theories are applied to explain the effect of the adoption of e-procurement and the internal control system on the prevention of fraudulent procurement of goods and services in the public sector.

Prosocial Organizational Behavior Theory. (Bief and Motowidho, 1986) define prosocial organizational behavior theory as behavior or actions taken by members of an organization against individuals, groups, or organizations proposed to improve the welfare of individuals, groups, or organizations (Ahmad, 2017). This theory assumes that every prosocial behavior (prosocial behavior) aims to benefit or provide benefits to others. Prosocial behavior can be motivated by self-care motives, good ethics, and may also be acts of help that are carried out without any desire for profit or reward (Mahmuda, 2011).

(Micela and Near, 1985) suggest that whistleblowers report alleged violations to help victims and provide benefits to the organization because they believe that the violations are not following the values held by the organization. In essence, a whistleblower is a prosocial behavior that emphasizes the actions taken to help others in making the organization healthy both public and private. The Government's Goods and Services Procurement Policy Agency (Lembaga Kebijakan Pengadaan Barang/Jasa Pemerintah/LKPP) established one whistleblowing system as a means for someone who wants to report fraud.

It can be stated that prosocial organizational behavior theory refers to prosocial behavior that emphasizes helping and providing benefits to the organization by giving out information. In this research, organizational behavior theory is used to explain the effect of the application of the whistleblowing system on the prevention of fraudulent procurement of the stuufs and services in the public sector.

E-Procurement. An digital procurement of goods and services system have to be entirely carried out due to the fact the 2012 fiscal year. (Brando and Carey, 2011) states that e-procurement is a procurement manner that refers to internet customers as a skill of statistics and communication.This was once demonstrated in Presidential Regulation No. 70 of 2012 regarding the procurement gadget of authorities goods and services. The motive and advantages of e-procurement, following the selection of the President of the Republic of Indonesia Number 70 of 2012 concerning suggestions for the procurement of government items and services, states that the procurement of goods and services ambitions to extend transparency and accountability, develop market get entry to and fair commercial enterprise competition, enhance the degree of method efficiency procurement of goods and offerings in government, Supporting the procedure of monitoring and auditing, meeting the want for get right of entry to to real-time statistics. Implementation methods according to (Willem, 2012) in e-procurement activities; e-Tendering, e-Bidding, e-Catalog, and e-Purchasing (procedures for 
purchasing goods and services through e-Catalog facilities) are four methods for implementing electronic procurement.

Whistleblowing System. Regulation of the Head of LKPP Number 11 of 2014 regarding the whistleblowing system for the procurement of authorities items and services, the $2 \mathrm{~d}$ section of article three (three) explains that the whistleblowing machine is a machine for processing complaints that are used by way of whistleblowers to complain of alleged violations in the subject of items and offerings procurement. The cause of whistleblowing is to amplify efforts to forestall and eradicate criminal acts of corruption, collusion, and nepotism $(\mathrm{KKN})$ in the procurement of items and services, motivate disclosure of irregularities or misuse of authority in the procurement of items and services, and improve supervision systems that guard whistleblowers in the framework of eradication of corruption in the procurement of government goods and services (Ahmad, 2017).

The meaning of whistleblower in Indonesia is indicated by the behavior of someone who reports fraud, where the fraud is an act in the form of a criminal act of corruption in the workplace organization so that it has a connection or information on the criminal act of corruption, besides reporting criminal acts of corruption whistleblower can also report cases others that violate the law and cause harm or threat to the welfare of society. An example of the most popular whistleblowing case in Indonesia is the story of Sudirman Said in the "papa asking for shares" case in which the report contains alleged suspects asking for several PT Freeport Indonesia's shares on behalf of the Republic of Indonesia's President and Vice President. From this case, the whistleblowing role is very large to protect and reduce the occurrence of acts of corruption or misappropriation of funds by using positions for personal satisfaction.

Internal Control System of Government. According to (COSO, 2013), the internal control system has 5 components, particularly the manage environment, hazard assessment, manipulate activities, records and communication, and monitoring and monitoring. An interior manage gadget is a process that entails actions and things to do carried out continually by using the management and all personnel to reap the goals and imaginative and prescient and mission that has been set (Lisa, 2013). Presidential Regulation of the Republic of Indonesia Number 4 of 2015 regarding the procurement of goods and services in principle referred to consists of seven fundamental concepts namely: efficient, effective, transparent, open, competitive, non-discriminatory, accountable.The methods of procurement of goods and services in Presidential Regulation No. 70 of 2012 include public auctions, limited auctions, simple auctions, direct selection of elections provide adequate confidence about the public, simple selection, competition, direct appointment, direct service.

Effective internal control is needed in implementing prevention strategies, by building and implementing internal controls, the internal control system existence is expected to minimize the level of deviation carried out. (Tunakotta, 2012) states that there are other concepts to prevent fraud in addition to internal control, which is to instill awareness about fraud (fraud awareness). Anti-fraud awareness according to (Bank Indonesia, 2011) is an awareness of the importance of efforts to prevent fraud by 
all parties in the organization. Through good leadership and accompanied by high awareness of anti-fraud, it can foster concern for all parties in the organization.

The Impact of Implementation of E-Procurement on The Prevention of Fraudulent Procurement of Goods and Services. Based on Presidential Regulation No. 16 of 2018 states that e-procurement is a device of procurement of stuffs and offerings electronically. The levels of sequential procurement of items and services electronically are planning, forming a committee, prequalification, making ready gentle documents, evaluating bids, announcing, and refuting stages. According to (Purwanto, 2015), e-procurement is an utility to manage data on the procurement of items and services which consists of internet-based procurement information that is designed to reap an effective, environment friendly and built-in procurement process. An digital procurement machine for goods and services is a solution that can improve the prevention of fraud in the procurement in the public sector.

The aim of stopping fraudulent procurement of goods and offerings electronically in the public zone can be to amplify transparency and accountability, increase market get entry to and commercial enterprise competition, enlarge the stage of efficiency of the procurement process, assist the monitoring and audit method and meet the latest facts needs. More and greater customers of digital items and offerings procurement both tenders and non-tenders whereby the e-procurement things to do there are 4 methods of implementation specifically e-Tendering, e-Bidding, e-Catalog, and e-Purchasing (procedures for buying goods and services through e-catalog), with the technique of imposing electronic procurement of items and offerings can extend the prevention of fraud procurement in the public sector. The results of lookup by means of Lintansari, (Hapsari and Budiono, 2017) country that the e-procurement variable has a wonderful effect on fraud prevention. The consequences of this study are strengthened with the aid of the lookup of (Neupane et al., 2012) which indicate that anti-corruption capabilities of public e-procurement, particularly the automation and audit trail capabilities can potentially increase the transparency and accountability of the government procurement process. Furthermore, benefits include increasing competition among bidders, best quality of work and services, and increasing more consistency in government procurement, which helps governments to reduce corruption in public procurement. Thus, the first speculation proposed in this study is:

H1: E-procurement has positive effect on the prevention of fraudulent procurement of goods and services.

The Effect of Applying The Whistleblowing System on The Prevention of Fraudulent Procurement of Goods and Services. Whistleblowing System is a device that can be accessed by means of everyone who has an urgent pastime such as to file a fraud that occurred, anybody who reviews a fraud is referred to as a whistleblower. According to (Nugroho, 2015), a machine of reporting violations or generally referred to as a whistleblowing machine is a potential or container for a whistleblower to record fraud or violations dedicated by means of an interior party. (Mardiasmo, 2017) explains that the duty to report, disclose, and be responsible for the success or failure of the implementation of the organization's mission in attaining predetermined results, through 
the media of accountability is executed periodically. By imposing an advantageous whistleblowing gadget can make bigger the prevention of fraud procurement of goods and services in the public sector. This announcement is supported by means of research with the aid of (Wahyuni and Nova, 2018) which states that the whistleblowing device variable has a positive effect on fraud prevention. The consequences of the find out about were verified through (La ode et al., 2019) which referred to that the whistleblowing gadget had a tremendous impact on fraud prevention in government. Therefore, the 2 nd hypothesis proposed in this learn about is:

H2: Whistleblowing system has positive effect on the prevention of fraudulent procurement of goods and services.

The Effect of The Implementation of The Internal Control System of Government on The Prevention of Fraudulent Procurement of Goods and Services. Presidential Regulation Number 60 the Year 2008 states that the manipulate device should implement elements such as the Control Environment, risk assessment, manage activities, statistics and communication, and monitoring. (Tunakotta, 2012) states that there are other principles in the prevention of fraud in addition to internal control, which is to instill awareness about fraud (awareness). Effective internal manage is very much needed in imposing prevention strategies, consequently the implementation of interior manage is anticipated to be a deterrent in opposition to such deviations. The greater the expectations of the interior manage system, the greater the stage of preventing fraud in the procurement of items and services, the advent of environment friendly and tremendous procurement of items and services. Research by means of (Wardana et al., 2017) states that the internal manipulate system variables that exist at the Buleleng Regency Public Works Office have a advantageous effect on fraud prevention. This occurs by lookup (Yasa, 2018) that government inner manipulate has a positive impact on fraud prevention in the public sector. Based on this description, the third hypothesis of this study is:

H3: Internal control system of government positively affects the prevention of fraudulent procurement of goods and services.

Research Model. Based on the description of the hypotheses above, the research framework is described as follows: 


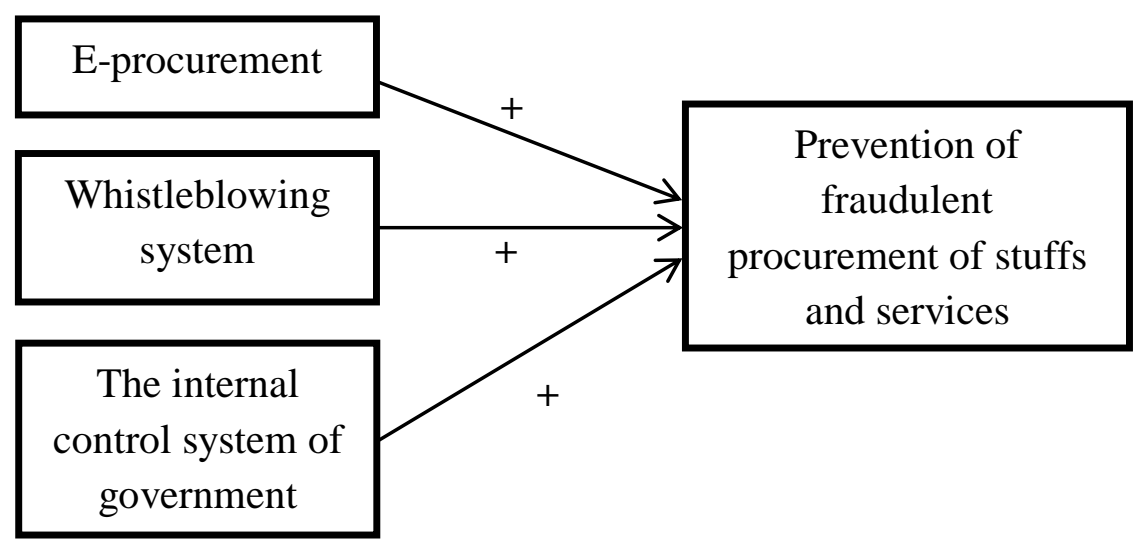

Figure 1. Research Model

\section{METHODS}

This research was conducted at the Yogyakarta City Government agencies. The population in this study are all State Civil Servants (Aparatur Sipil Negara/ASN) in the Procurement Service Units (Unit Layanan Pengadaan/ULP), the Inspectorate, and the Health Service in Yogyakarta City. The method used for sampling in this study is purposive sampling method. The samples used were State Civil Servants in the Procurement Service Units, Inspectorate, and Health Service in Yogyakarta City who had participated in goods and service procurement activities for at least 1 year.

Table 1. Questionnaire Distribution

\begin{tabular}{lc}
\hline \multicolumn{1}{c}{ Description } & Number of questionnaires \\
\hline Questionnaire was distributed & 75 \\
Questionnaire were not returned & 7 \\
Questionnaire was used & 68 \\
Response rate = 68/75 x 100\% & $91 \%$ \\
\hline
\end{tabular}

Source: (Primary data processed 2020)

Data collection was carried out using survey techniques using an instrument in the form of a questionnaire distributed in May 2019. Based on 68 data collected and 7 nonreturn questionnaires, the response rate of the questionnaire distributed was $91 \%$.

Operational Definition and Research Variable. The variable for preventing fraud in the procurement of stuffs and services is measured by 3 indicators with 8 statements on the questionnaire. 
Wardani, Primastiwi, and Hanisah: Fraud Prevention of Government Procurement ...

Table 2. Measurement of Goods and Services Procurement Fraud Prevention Variables

\begin{tabular}{llll}
\hline Variable & \multicolumn{1}{c}{ Operational Definition } & Indicator & Scale \\
\hline $\begin{array}{l}\text { Prevention fraud } \\
\text { procurement }\end{array}$ & $\begin{array}{l}\text { Fraud prevention is an attempt or } \\
\text { attempt to refuse or restrain all }\end{array}$ & $\begin{array}{l}\text { 1. } \\
\text { goods and services } \\
\text { commision by audit }\end{array}$ & Ordinal \\
forms of action dishonest that & 2. Responsibility & \\
could result opportunity for loss or & management for & \\
& $\begin{array}{l}\text { lossthat is real for the company, } \\
\text { employees,and others (Wulandari, }\end{array}$ & $\begin{array}{l}\text { evaluate prevention } \\
\text { fraud. }\end{array}$ \\
& 2017). & $\begin{array}{l}\text { 3. Culture of being } \\
\text { honest and high } \\
\end{array}$ & ethics \\
\end{tabular}

The indicators of e-procurement variables will be measured by 2 indicators with 18 statements on the questionnaire.

Table 3. Measurement of E-Procurement Application Variables

\begin{tabular}{|c|c|c|c|}
\hline Variable & Operational Definition & Indicator & Scale \\
\hline $\begin{array}{l}\text { E-Procurement } \\
\text { (EPROC) }\end{array}$ & $\begin{array}{l}\text { E-procurement is an application } \\
\text { to manage procurement data } \\
\text { and services electronically so that it } \\
\text { canproduce effective, efficient, and } \\
\text { integrated procurement (Rithm } \\
\text { \&Nuryanti, 2015). }\end{array}$ & $\begin{array}{l}\text { 4. Stages implementation } \\
\text { of e-procurement } \\
\text { 5. Method } \\
\text { implementation of e- } \\
\text { procurement }\end{array}$ & Ordinal \\
\hline
\end{tabular}

Whistleblowing system variable as measured by 4 indicators outlined in the 8 statements.

Table 4. Measurement of Whistleblowing System Implementation Variables

\begin{tabular}{|c|c|c|c|}
\hline Variable & Operational Definition & Indicator & Scale \\
\hline $\begin{array}{l}\text { Whistleblowing } \\
\text { system } \\
\text { (WBLOW) }\end{array}$ & $\begin{array}{l}\text { A whistleblowing system is disclosure } \\
\text { information by members of the } \\
\text { organization which is seen as practice } \\
\text { illegal, immoral, or not legally under } \\
\text { the employee's candidacy to people or } \\
\text { possible organization affect action } \\
\text { (Wulandari, 2017). }\end{array}$ & $\begin{array}{l}\text { 6. Effectiveness application } \\
\text { whistleblowing system } \\
\text { 7. How to report an offense } \\
\text { 8. Benefits whistleblowing } \\
\text { system } \\
\text { 9. The role for interests } \\
\text { public }\end{array}$ & Ordinal \\
\hline
\end{tabular}

The internal control system of government variables is measured by 5 indicators outlined in the 16 statements. 
Table 5. Measurement of Government Internal Control System Variables

\begin{tabular}{lllc}
\hline Variable & \multicolumn{1}{c}{ Operational Definition } & \multicolumn{1}{c}{ Indicator } & Scale \\
\hline The internal control & SPIP is an integral procedure of & 10. Control & Ordinal \\
system of & movements and things to do carried & environment & \\
government (SPIP) & out consistently by way of the & 11. Risk assessment & \\
& leadership and all employees to supply & 12. Control activities & \\
& sufficient self belief in the & 13. Information and & \\
& achievement of organizational dreams & communication \\
& via nice and efficient things to do & 14. Monitoring & \\
& (Sabrida, 2018).
\end{tabular}

Data Analysis Method. The data analysis technique used in this study is the analysis of Structural Equation Model - Partial Least Square (SEM-PLS) method and is assisted by the SmartPLS 3 statistical program. The outer model is a measurement model to assess the validity and reliability of the model, while the inner model is a structural evaluation to assess the relationship between constructs or latent variables.

\section{RESULTS}

Descriptive Statistics. The results of the descriptive statistics showed in the table below:

Table 6. Descriptive Statistics Test

\begin{tabular}{|c|c|c|c|c|c|}
\hline Variables & $\mathbf{N}$ & Minimum & Maximum & Mean & $\begin{array}{c}\text { Std. } \\
\text { Deviation }\end{array}$ \\
\hline E-procurement & 68 & 54 & 90 & 72.66 & 6.720 \\
\hline Whistleblowing system & 68 & 22 & 34 & 27.78 & 2.134 \\
\hline $\begin{array}{l}\text { The internal control system of } \\
\text { government (SPIP) }\end{array}$ & 68 & 43 & 70 & 56.97 & 4.769 \\
\hline $\begin{array}{l}\text { Prevention of fraud procurement } \\
\text { of goods and services }\end{array}$ & 68 & 24 & 39 & 32.22 & 2.625 \\
\hline
\end{tabular}

Source: (Primary data processed 2020)

The average value of respondents' answers for the e-procurement variable is 72.66, standard deviation is 6.720, with the maximum value if the respondent thinks that e-procurement in Yogyakarta City is very good is 90, then it can be said that the respondent states the application of e-procurement in the Yogyakarta City is good. The average value of the respondent's answer to the whistleblowing system variable is 27.78 , the standard deviation is 2.134 , with the maximum value if the respondent thinks the whistleblowing system in Yogyakarta City is very good is 40, it can be seen that the respondent states that the application of the whistleblowing system in the Yogyakarta City is quite good. The average value of the respondents' answers to the SPIP variable is 56.97, the standard deviation is 4.769 , with the maximum value if the respondent thinks that SPIP in Yogyakarta City is very good is 70, then it can be seen that the respondent states that the application of SPIP in Yogyakarta City is good. The average value of respondents' answers for the prevention of fraud procurement of goods and 
services variable is 32.22 , the standard deviation is 2.625 , with the maximum value if the respondent thinks that Prevention of fraud procurement of goods and services in Yogyakarta City is very good is 40 , then it can be seen that the respondent stated that the implementation of prevention of fraud procurement of goods and services in Yogyakarta City is good.

Structural Equation Model. From the results of data processing with SEM analysis using SmartPLS software, a path diagram can be presented in the following figure.

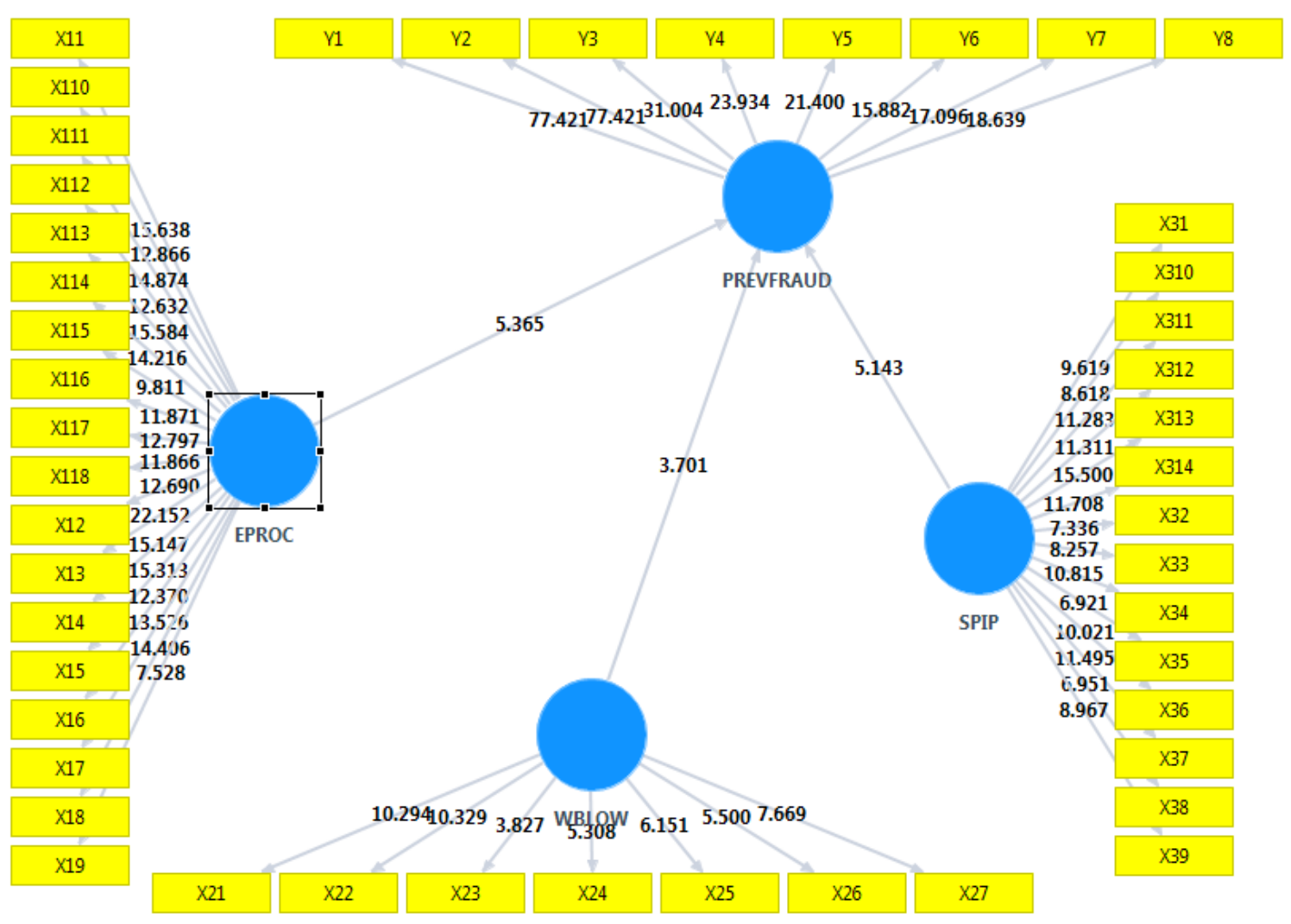

Figure 2. Result Model

Source: (Primary data processed, 2020)

Testing with the PLS method basically consists of 2 types of testing, namely the measurement model (outer model) and the structural model (inner model).

Outer Model or Measurement Model. The outer model test results in Figure 2 show that the outer loading value of each indicator on each variable is more than 0.5 , so it can be concluded that all variables have met the requirements of model adequacy or discriminant validity. Another test to assess the construct validity is by seeing the AVE value. In this study, the AVE value of the e-procurement, whistleblowing system, and internal control systems of government and the prevention of fraudulent procurement of 
goods and services was $0,586,0,568,0,583$, and 0,823 . This value is greater than 0.50 , so it can be said that all constructs meet the criteria for construct validity.

In addition to the construct validity test, a construct reliability test was also carried out as measured by two criteria, namely composite reliability and cronbach alpha from the indicator block measuring the construct. The value of composite reliability is quite high in the construct of e-procurement, whistleblowing system, and internal control systems of government and the prevention of fraudulent procurement of goods and services above 0.70 . The value of composite reliability in the construct of eprocurement, whistleblowing system, and internal control systems of government and the prevention of fraudulent procurement of goods and services respectively is 0,962 , $0,859,0,929$, and 0,974 , so it can be said that all constructs are reliable.

Inner Model or Structural Model Testing. Model assessment with PLS begins by looking at the R-square for each dependent latent variable.

Tabel 7. R-Square

\begin{tabular}{|c|c|c|c|c|c|}
\hline \multicolumn{6}{|c|}{$\begin{array}{l}\text { R Square } \\
\text { Mean, STDEV, T-Values, P-Values }\end{array}$} \\
\hline & $\begin{array}{c}\text { Original } \\
\text { Sample } \\
(\text { O) }\end{array}$ & $\begin{array}{c}\text { Sample } \\
\text { Mean } \\
\text { (M) } \\
\end{array}$ & $\begin{array}{c}\text { Standard } \\
\text { Error } \\
\text { (STERR) }\end{array}$ & $\begin{array}{c}\text { T Statistics } \\
(\mid \text { O/STERR } \mid)\end{array}$ & P Values \\
\hline PREVFRAUD & 0.522 & 0.573 & 0.057 & 9.159 & 0.000 \\
\hline
\end{tabular}

Table 7 shows the employee performance variable has an R-square value of 0.522 , which means that $52.2 \%$ of the variance in the prevention of fraudulent procurement of goods and services variables can be explained by the variable of eprocurement, whistleblowing system, and internal control systems of government. Thus it can be said that this research model is good at explaining the dependent variable.

Hypothesis Testing. Hypothesis testing is carried out by looking at the magnitude of the T-statistic value on the output of result for path coefficients. The significance of the parameters estimated provides very useful information about the relationship between the research variables. 
Table 8. Result for Path Coefficients

\begin{tabular}{lccccc}
\hline $\begin{array}{l}\text { Path Coefficients } \\
\text { Mean, STDEV, T-Values, P-Values }\end{array}$ & & & & \\
& $\begin{array}{c}\text { Original } \\
\text { Sample } \\
(\mathbf{O})\end{array}$ & $\begin{array}{c}\text { Sample } \\
\text { Mean } \\
(\mathbf{M})\end{array}$ & $\begin{array}{c}\text { Standard } \\
\text { Error } \\
(\text { STERR })\end{array}$ & $\begin{array}{c}\text { T Statistics } \\
(\mid \mathbf{O} / \text { STERR })\end{array}$ & $\begin{array}{c}\text { P } \\
\text { Value } \\
\text { s }\end{array}$ \\
\hline $\begin{array}{lccccc}\text { E-PROC -> } \\
\text { PREVFRAUD }\end{array}$ & 0.376 & 0.382 & 0.070 & 5.365 & 0.000 \\
\hline $\begin{array}{l}\text { SPIP -> } \\
\text { PREVFRAUD }\end{array}$ & 0.390 & 0.398 & 0.076 & 5.143 & 0.000 \\
\hline $\begin{array}{l}\text { WBLOW -> } \\
\text { PREVFRAUD }\end{array}$ & 0.285 & 0.300 & 0.077 & 3.701 & 0.000 \\
\hline Source: (Primary data processed 2020) & & & &
\end{tabular}

From result for path coefficients above it can be interpreted that the implementation of internal control systems of government (SPIP) has a stronger influence on the prevention of fraudulent procurement of goods and services (PREVFRAUD) than other variables. This is indicated by the variable path coefficient of internal control systems of government (SPIP) of 0.390 which is greater than the coefficient of e-procurement variable (EPROC) of 0.376 and the coefficient of whistleblowing system variable (WBLOW) of 0.285 .

Hypothesis 1: E-procurement has positive effect on the prevention of fraudulent procurement of goods and services. From the test results, it was found that the eprocurement variable (EPROC) had an original sample estimate value of 0.376 indicating that the relationship between e-procurement and the prevention of fraudulent procurement of goods and services was positive, while for the T statistic it was 5.365. By using a significance of 0.05 ( $\mathrm{T}$ statistic $>\mathrm{T}$ table 1.96) and the calculation of path coefficient which shows the direction of the relationship, hypothesis one (H1) which states that e-procurement variable (EPROC) has a positive effect on the prevention of fraudulent procurement of goods and services (PREVFRAUD) is supported by existing data. Based on the results of these tests, it can be concluded that hypothesis one (H1) which represents the positive effect of e-procurement on the prevention of fraudulent procurement of goods and services is supported.

Hypothesis 2: Whistleblowing system has positive effect on the prevention of fraudulent procurement of goods and services. From the test results, it is found that the whistleblowing system variable (WBLOW) had the original sample estimate value of 0.285 indicating that the relationship between whistleblowing system and the prevention of fraudulent procurement of goods and services was positive, while for the $\mathrm{T}$ statistic it was 3.701. By using a significance of 0.05 ( $\mathrm{T}$ statistic $>\mathrm{T}$ table 1.96) and the calculation of path coefficient which shows the direction of the relationship, hypothesis two (H2) which states that whistleblowing system variable (WBLOW) has a positive effect on the prevention of fraudulent procurement of goods and services (PREVFRAUD) is supported by existing data. Based on the results of these tests, it can be concluded that hypothesis two $(\mathrm{H} 2)$ which represents the positive effect of 
whistleblowing system on the prevention of fraudulent procurement of goods and services is supported.

Hypothesis 3: Internal control system of government positively affects the prevention of fraudulent procurement of goods and services. From the test results, it was found that the variable of internal control systems of government (SPIP) had the original sample estimate value of 0.390 indicating that the relationship between iinternal control systems of government and the prevention of fraudulent procurement of goods and services was positive, while for the $\mathrm{T}$ statistic it was 5.143. By using a significance of 0.05 ( $\mathrm{T}$ statistic $>\mathrm{T}$ table 1.96) and the calculation of path coefficient which shows the direction of the relationship, hypothesis three (H3) which states that variable of internal control systems of government (SPIP) has a positive effect on the pretention of fraudulent procurement of goods and services (PREVFRAUD) is supported by existing data. Based on the results of these tests, it can be concluded that hypothesis three (H3) which represents the positive effect of internal control systems of government on the prevention of fraudulent procurement of goods and services is supported.

\section{DISCUSSION}

Hypothesis 1. Hypothesis one (H1) is supported, so it can be said that e-procurement has a positive effect on the prevention of fraud in the procurement of goods and services, or it can be said that e-procurement can help prevent fraud in the procurement of goods and services. The consequences of checking out this hypothesis can show that the maximum prevention of procurement of goods and offerings fraud if the application of e-procurement is applied to the most within the authorities' agency. The implementation of e-procurement in the public quarter can make bigger the transparency of the procurement process, make bigger accountability, and help monitoring and auditing, grant real-time information, and provide huge understanding to the public concerning the procurement of items and offerings so that the public participates and oversees at some point of the procurement technique and digital services.

This opinion is strengthened by the respondent's assessment obtained through sixty-eight questionnaires distributed to the goods and services procurement actors who are in the Procurement Service Unit (Unit Layanan Pengadaan/ULP), Inspectorate, and Yogyakarta City Health Office. The majority of respondents' answers agree, so it can be concluded that the electronic procurement system can prevent fraud that occurs during the process of procuring goods and services. This electronic procurement system can reduce procurement inefficiencies by providing benefits that exceed costs. The use of eprocurement for the government is a concrete manifestation of the application of the principles of good governance, namely transparent and accountable procurement. This is in accordance with the theory of bureaucratic reform in which improvements, changes, or improvements to a system and organization are made to achieve good governance. One of the reforms in government is to change the process of procuring goods and services from conventional to electronic procurement of goods and services. In a conventional procurement system the parties involved in the procurement auction process, namely providers and users, meet and make physical contact. In conventional 
procurement systems also tend to be more closed because the dissemination of information tends not to be optimal. On the other hand, the electronic goods and services procurement system is carried out openly, there is no physical contact between providers and users, and can be monitored by all parties and the wider community, so it can be said that this system is more transparent.

Hypothesis 2. Hypothesis two ( $\mathrm{H} 2)$ which states that the whistleblowing system has a positive effect on the prevention of fraudulent procurement of goods and services is supported. Thus it can be concluded that the whistleblowing has a positive effect or contributes to the prevention of fraudulent procurement of goods and services. The results of this study indicate that the higher application of the whistleblowing system, the higher the level of fraud prevention in the procurement of goods and services in the Yogyakarta City.

Someone who wants to report fraud or irregularities that occur in an agency through the system, it can be said that the whistleblowing system provides benefits and facilitates someone who reports fraud without any pressure or threat from the relevant parties, because in Regulation No. Law. 31 of 2014 where the contents of the regulation are legal protections against whistleblowers or protection of witnesses and victims. The benefits to be gained from the implementation of the whistleblowing system is that it can prevent the occurrence of fraudulent procurement of goods and services because someone will be afraid of cheating. After all, the whistleblower is always watching without realizing it. This is under prosocial organization behavior theory, namely, the behavior of a person can be motivated by self-care motives, good ethics, and may also be acts of help that are carried out without any desire for profit or reward.

Hypothesis 3. Testing of hypothesis 3 (H3) shows that hypothesis is supported so that it can be concluded that the government internal control system (SPIP) has a positive effect or makes a positive contribution to the fraud prevention variable in the procurement of goods and services. The outcomes of this find out about indicate that the greater the most software of the internal control systems of government, the greater the level of fraud prevention of procurement of goods and services. Government Regulation No. 60 of 2008 describes the inside control device which is more targeted on smooth control which includes ethics, morality, integrity, honesty, discipline, competence, commitment, and getting to know different software.

The internal control systems of government can prevent the prevalence of fraudulent procurement of goods and services via implementing the most gentle control so that the opportunity to commit fraud can be minimized. The nature of the inside manipulate system is that it is built-in and is a procedure that is continually carried out by means of government corporations and is dynamic and often floating in time to create right governance in the government. The characteristic of the inner manage device is as a benchmark for trying out effectiveness, thinking about components of fees and benefits, and the development of information technology. This is below the theory of bureaucratic reformation in which the inside control machine as a guide for the implementation of the package of state monetary reform closer to right governance or accurate governance. 


\section{CONCLUSION}

The respondents of this study were 68 procurement staff in the Procurement Services Unit (ULP), in the Regional Apparatus Work Units namely the Inspectorate, and in the Yogyakarta City Health Office in Yogyakarta City. Based on what has been amassed and the results that have been finished with the assist of SmartPLS statistical program, it can be concluded that e-procurement has a nice and sizable effect on stopping the fraud of procurement of goods and services. A whistleblowing machine has a positive and great impact on preventing fraud in the procurement of goods and services. The inner manipulate device of government has a fantastic and substantial effect on stopping fraud in the procurement of goods and services.

Respondents assessed that the implementation of e-procurement in Yogyakarta City is good, that the level of application of the whistleblowing system was still quite good (considered to be at a moderate level), while the implementation of the government internal control system was good. The respondents also thought that the efforts to prevent fraud in the procurement of goods and services in the Procurement Service Unit and the Yogyakarta City Regional Apparatus Work Unit is good.

Based on the results of the analysis, it can be concluded that the Yogyakarta City Government must continue to implement and improve the e-procurement system, whistleblowing system, and internal control system within the authority through SPIP because these three elements can reduce the loopholes for fraud in the procurement of goods and services. In line with the results of research by (Neupane et al., 2012), the Yogyakarta City Government, as part of Indonesia as a developing country, certainly has objectives that are in line with the objectives of the most of the developing countries, namely that most of the developing countries government missions and objectives of adopting e-procurement technology are to increase transparency, accountability, real time access information, and increase competition among bidders, which ultimately reduces corruption in public procurement. To increase transparency and accountability in the procurement of goods and services requires a strong commitment from the government as a policy maker and from the actors in the procurement of goods and services to carry out the procurement of goods and services through e-procurement properly.

Suggestion. The Yogyakarta City Government needs to improve the application of the e-procurement system, implement a whistleblowing system, and apply a control system within the authority through SPIP so that the system for procurement of goods and services in Yogyakarta City becomes more transparent and accountable. Other than that, this research has a limitation in whichthe research data uses only one data source using a questionnaire so that the data obtained only describes the opinions of respondents in writing. Thus, the respondents' opinions expressed do not necessarily reflect the actual situation. Therefore, further researchers should conduct interviews so that they can control respondents' answers. The next researcher also can add research variables such as the provision of compensation to the staff of the procurement of goods and services and the application of the principles of good corporate governance. 


\section{REFERENCES}

Achmad Nasution. (2016). Analisis Penerapan Sistem Pengendalian Internal Pemerintah ( SPIP ) Oleh : Achmad Nasution Pendahuluan Pengendalian Intern. Analisis Penerapan Sistem Pengendalian Intern Pemerintah (SPIP), 3(1), 73-82.

Agusyani, N. K. S., Sujana, E., dan Wahyuni, M. A. (2016). Pengaruh whistleblowing system dan kompetensi sumber daya manusia terhadap pencegahan fraud pada pengelolaan keuangan penerimaan pendapatan asli daerah. E-Journal $A k$ Universitas Pendidikan Ganesha, 6(3).

AKBAR, A. (2017). Pengaruh kompetensi auditor dan peran whistleblower terhadap pendeteksian kecurangan pada pengadaan barang dan jasa. Skripsi, 1(3), 1-88.

Albrecht, C. O., Holland, D. V, Skousen, B. R., and Skousen, C. J. (2018). The Significance of Whistleblowing as an Anti-Fraud Measure. Journal of Forensic \& Investigative Accounting, 10(1), 1-13.

Artantri, L. P. R. M., Handajani, L., dan Pituringsih, E. (2016). Peran E-Procurement Terhadap Pencegahan Fraud Pada Pengadaan Barang/Jasa Pemerintah Daerah Di Pulau Lombok. NeO Bis, 10(1), 16-32.

Azmi, L. M., Herwanti, T., and Asmony, T. (2017). E-procurement fraud in government sector: In the perspective of fraud diamond theory. E-Proceeding Stie Mandala, $0(0), \quad 14363 . \quad$ Retrievedfrom http://jurnal.stiemandala.ac.id/index.php/eproceeding/article/view/131.

Bafakih, A. (2013). Whistleblower System Dalam Proses Pengadaan Barang/Jasa Untuk Mencegah Persengkongkolan Tender (Bid Rigging) Yang Dapat Mengakibatkan Terjadinya Persaingan Usaha Tidak Sehat. Skripsi, 1-20.

Basri, S. A., Marsam, A. D., Majid, R. A., Abu, N. 'Asyiqin, and Mohamed, N. (2017). Reinforcement Tool of Whistleblowing to Eradicate Fraud in Public Sector. SHS Web of Conferences,36, 00038. https://doi.org/10.1051/shsconf/20173600038.

Brief, A., and Motowidlo, S. J. (2017). Prosocial Organizational Behaviors. (October 1986). https://doi.org/10.2307/258391.

Dewi, V. (2018). Pengaruh Penerapan E-Procurement Pengadaan Barang dan Jasa Pemerintah Untuk Mencegah Fraud Pada Biro Administrasi Pembangunan dan Pengadaan Barang dan Jasa. Skripsi, 1(September), 160-164.

Faisol, Tarjo, M. (2013). Pengaruh Penerapan E-procurement Terhadap Pencegahan Kecurangan Pengadaan Barang di Sektor publik.

Ghozali, I. (2013). Analisis Multivariate dengan program IBM SPSS 16. 16.(6th ed) Semarang:Badan Penerbit Universitas Dipenerogo.

Hendrayady, A. Reformasi administrasi publik (2013). https://d1wqtxts1xzle7.cloudfront.net/35616197/REFORMASIADMINISTRASI-PUBLIK.

Hikmah, Y. N., Oktaroza, M. L., dan Purnamasari, P. (2018). Pengaruh Efektivitas Whistleblowing System dan Budaya Organisasi Terhadap Pencegahan Kecurangan (Survei pada Empat Badan Usaha Milik Negara Sektor Transportasi dan Pergudangan di Kota Bandung). Prosiding Akuntansu, 4(2), 518-523.

Judhanto, A. S. (2018). Pembentukan Holding Company BUMN dalam Perspektif Hukum Persaingan Usaha. Jurnal Spirit pro Patria, IV(2), 154-170. Retrieved from http://jurnal.narotama.ac.id/index.php/patria/article/view/675/392. 
Lanrewaju, S., and Dare, M. (2018). Whistleblowing As A Tool For Combating The Menace of Fraud, Forgery And Corruption in Nigeria. International Journal of Advanced Academic Research,4(3), 31-49.

Lintangsari, M., Wahyu Hapsari, D., dan Budiono, E. (2017). Pengaruh Implementasi E-Procurement dan Pengendalian Internal terhadap Pencegahan Fraud (Studi Empiris pada PT. PLN (Persero) Distribusi Jawa Barat dan Banten) The Effect of E-Procurement Implementation, Internal Control of Preventing Fraud (Empirical Stu. Jurnal Akuntansi, 4(3), 2661.

LKPP. (2014). Lembaga Kebijakan Pengadaan Barang dan Jasa Pemerintah Repoblik Indonesia. 1-12.

Merawati, L. K., dan Mahaputra, I. N. K. A. (2017). Moralitas, Pengendalian Internal Dan Gender Dalam Kecenderungan Terjadinya Fraud. Jurnal Akuntansi, 21(1), 35. https://doi.org/10.24912/ja.v21i1.132.

Neupane, A., Soar, J., Vaidya, K., and Yong, J. (2012). Role of Public E-procurement Technology to Reduce Corruption in Government Procurement. International Public Procurement Conference, Seattle Washington, 304-334.

Nisak, C., Fitri, P., dan Kurniawan, A. (2013). Sistem Pengendalian Intern Dalam Pencegahan Fraud Pada Satuan Kerja Perangkat Daerah (SKPD) Pada Kabupaten Bangkalan. Jaffa, 01(1), 15-22.

Nova, E. S. W. dan T. (2018). Analisis Whistleblowing System dan Kompetensi Aparatur Terhadap Pencegahan Fraud. 6, 189-194.

Nugroho, R. (2015). Pengaruh Implementasi Sistem Pengadaan Secara Elektrinik (EProcurement) Terhadap Fraud Pengadaan Barang/Jasa Pemerintah (Studi Pada Satuan Kerja Perangkat Daerah Kabupaten Magetan). Jurnal Administrasi Publik Mahasiswa Universitas Brawijaya, 3(11), 1905-1911.

Oguda, N. J., Odhiambo, A., and Byaruhanga, J. (2015). Effect of Internal Control on Fraud Detection and Prevention in District Treasuries of Kakamega County. International Journal of Business and Management Invention, 4(1), 47-57.

Oktaviani, L. (2017). Pengaruh Penerapan E-Procurement Terhadap Pencegahan dan Pendeteksi Fraud Di Sektor Publik. Skripsi, 01, 1-26. Retrieved from http://www.albayan.ae.

Pratiwi, E. T., Abdullah, R., and Abdullah, L. O. D. (2019). Whistleblowing Systems as an Initial Effort to Prevention and Detection of Fraud. 73(Aicar 2018), 22-26. https://doi.org/10.2991/aicar-18.2019.6

Publik, D. I. S. (2014). Pengaruh penerapan e-procurement terhadap pencegahan kecurangan. 02(2), 71-90.

Purwanto, E., dan Setiawan, A. B. (2015). Implementasi Sistem Pengendalian Internal Pemerintah Terhadap Proses Pengadaan Barang Dan Jasa Pada Satuan Polisi Pamong Praja Kota Bogor Internal Control System Implementation of Government of Procurement Processes and Services on Satuan Polisi Pamong Pr. 1(2), 13-22.

Purwitasari, A. (2017). Pengaruh Pengendalian Internal Dan Komitmen Organisasi Dalam Pencegahan Fraud Pengadaan Barang (Survey pada 5 Rumah Sakit di Bandung). Skripsi, 2(4), 1-127. https://doi.org/10.1016/S0140-6736(79)91018-3. 
Sabrida, A., dan Br, T. (2018). Pengaruh Efektifitas Sistem Pengendalian Intern Pemerintah Terhadap Pencegahan Fraud (Studi Kasus pada Kota Medan). Skripsi, 2(4), 1-105.

Salim, M., Syarifuddin, dan Syamsuddin. (2016). Efek moderasi komitmen organisasi pada pengaruh implementasi $e$ - procurement terhadap pencegahan fraud pengadaan barang dan jasa pemerintah. Jurnal Analisis, 5(2), 178-185.

Tiro, A. A. A. (2014). Pengaruh Pengendalian Internal Dan Kompensasi Terhadap Kecenderungan Kecurangan (Fraud) Pada Pemerintah Kota Palopo. Skripsi, 1106.

Wahyuni, N. (2017). Pengaruh Pelaksanaan Sistem Pengendalian Internal dan Moralitas Pegawai Terhadap Pencegahan Fraud. Jurnal Simposium Nasional Akuntansi, $4(2), 1-32$.

Wardana, I. G. A. K., Sujana, E., dan Wahyuni, M. A. (2017). Pengaruh Pengendalian Internal, Whistleblowing System Dan Moralitas Aparat Terhadap Pencegahan Fraud Pada Dinas Pekerjaan Umum Kabupaten Buleleng. E-Journal S1 Ak Universitas Pendidikan Ganesha, 8(2), 1-10.

Wedya, A. (2013). Pengaruh Sistem Pengendalian Internal Pemerintah Dalam Fraud Barang dan Jasa Pada Instansi Pemerintah. Skripsi, 53(9), 1689-1699. https://doi.org/10.1017/CBO9781107415324.004.

Wulandari, D. N., dan Nuryanto, M. (2018). Pengaruh Pengendalian Internal, Kesadaran Anti-Fraud, Integritas, Independensi, dan Profesionalisme Terhadap Pencegahan Kecurangan. Jurnal Riset Akuntansi Mercu Buana, 4(2), 117. https://doi.org/10.26486/jramb.v4i2.557.

Wulandari, T. (2017). Pengaruh Budaya Organisasi,Peran Audit Internal, dan Whistleblowing System Terhadap Pencegahan Kecurangan. Sk, 1-145. 